\title{
EKOLOŠKA PRIDELAVA OLJK V SLOVENIJI
}

\section{Dane Podmenik*, dr. Barbara Lampič**, dr. Martina Bavec***}

*dipl. univ. geograf, Montinjan 6, SI-6273 Marezige, e-mail: dane.podmenik@gmail.com

**Oddelek za geografijo, Filozofska fakulteta Univerze v Ljubljani, Aškerčeva 2, SI-1000 Ljubljana

e-mail: barbara.lampic@ff.uni-lj.si

***Fakulteta za kmetijstvo in biosistemske vede Univerze v Mariboru, Pivola I0, SI-23 I 2 Hoče e-mail: martina.bavec@uni-mb.si

\section{Izvirni znanstveni članek}

COBISS 1.01

DOI: $10.4312 /$ dela.39.3.49-66

\section{Izvleček}

V prispevku predstavljamo razvoj in značilnosti ekološke pridelave oljk v Sloveniji. V letu 2012 je bilo zabeleženih 184,5 ha ekoloških oljčnikov, kar predstavlja $10 \%$ vseh oljčnih nasadov. Glede na trende lahko v naslednjih letih pričakujemo, da bi se obseg ekoloških oljčnikov lahko povzpel na 350 ha. Pomembna je tudi ugotovitev, da pridelovalci namenjajo premalo pozornosti trajnostnim kmetijskim praksam, kar sproža kritičen premislek o izpolnjevanju temeljnih standardov ekološkega kmetijstva.

Ključne besede: oljkarstvo, ekološko kmetijstvo, ekološka pridelava oljk, trajnostna praksa, kmetijstvo, Slovenska Istra

\section{ORGANIC OLIVE GROWING IN SLOVENIA}

\begin{abstract}
The paper presents the development and characteristics of organic olive production in Slovenia. In 2012, there were 184.5 ha of organic olive orchards, which represent $10 \%$ of all olive orchards. In the coming years, we expect that the area of organic olive orchards, given the trends, could increase to 350 ha. We can resume from the research that farmers pay too little attention to sustainable agricultural practices, which raises critical reflections regarding the fulfillment of the essential standards of organic farming.
\end{abstract}

Key words: organic farming, organic olive production, sustainable practice, agriculture, Slovenian Istria 


\section{UVOD}

Zaradi podnebnih pogojev, ki ključno vplivajo na razširjenost oljke, ta tipična sredozemska rastlina uspeva pri nas le na območjih submediteranskega podnebja, kjer pa veliko nevarnost predstavljajo zimske (pre)nizke temperature oziroma pozebe, ki lahko v oljčnih nasadih naredijo veliko (ekonomsko) škodo. V 20. st. so se pozebe, ki so povzročile večje negativne posledice oziroma škodo, v povprečju pojavljale na približno vsakih 20 let (Ogrin, 2002). Kljub nevarnosti pozeb pa je oljkarstvo v zadnjih dvajsetih letih pri nas v velikem vzponu (Bandelj Mavsar in sod., 2008) in tako imamo danes okoli 1800 ha kmetijskih površin, posajenih z oljko (Evidenca pridelovalcev in ..., 2012). Velika večina oljčnih nasadov se nahaja na območju Slovenske Istre.

$\mathrm{Na}$ opisano rast je vplivala tudi intenzifikacija in modernizacija pridelave oljk, ki pa vzporedno, z večjimi donosi in prihodki, prinaša negativne posledice na okolje in naravne vire ter lahko vpliva tudi na degradacijo (tipične) kulturne pokrajine. Med najizrazitejše negativne okoljske učinke (intenzivnejše) pridelave oljk lahko uvrstimo erozijo, zmanjševanje vsebnosti humusa oziroma organskih hranil v prsti, onesnaževanje površinske in podtalne vode zaradi (prekomerne) rabe lahko topljivih mineralnih gnojil in pesticidov, pretirano izkoriščanje vodnih virov (za potrebe namakanja), zmanjševanje biotske raznovrstnosti ter onesnaževanje zraka zaradi prevladujočega strojnega dela (Beaufoy, 2001). Dodati velja še vprašanje ostankov pesticidov v olivah oziroma oljčnem olju zaradi rabe fitofarmacevtskih sredstev (Cunha in sod., 2010).

Kot učinkovit odgovor na intenzivno kmetijstvo se kaže uveljavljanje ekološke pridelave, katerega osnovno izhodišče je po Lampkinu (1994) okoljska, socialna in ekonomska trajnost. Bavčeva (2001) opredeljuje ekološko kmetijstvo kot način trajnostnega kmetijstva, ki pri pridelavi hrane temelji na ravnovesju v sistemu tla-rastline-živali-človek in sklenjenem kroženju hranil v njem. Poudarek je tako na pestrosti pridelave, izbiri okolju primernih oziroma tradicionalnih sort in vrst, ohranjanju rodovitnosti prsti, preventivni skrbi za zdravje rastlin, pri čemer imajo prednost naravni oziroma zeliščni pripravki pred dovoljenimi fitofarmacevtskimi sredstvi, čim manjšem vnosu snovi na kmetijo in porabi neobnovljivih virov, (dodatnem) izobraževanju in širši skrbi za ekološka vprašanja. Zelo pomembno vlogo igrajo prakse, kot so kolobarjenje, zeleno gnojenje ali setev vmesnih posevkov, ki imajo mnogokratne pozitivne učinke. Kot ključne cilje ekološkega kmetijstva lahko izpostavimo (Principles of organic agriculture, 2012):

- pridelava visoko kakovostnih živil;

- raznolikost pridelave in ohranjanje genetske raznovrstnosti;

- varovanje naravnih virov, biotske raznovrstnosti in ekosistemov;

- $\mathrm{z}$ uporabo trajnostnih praks in lokalnih virov skrbeti za varstvo rastlin in živali ter dolgoročno ohranjanje rodovitnosti in biološke aktivnosti tal;

- dobrobit živali;

- upoštevanje in zaščita (lokalnih) tradicionalnih kmetijskih znanj in praks;

- spodbujanje lokalne in regionalne pridelave ter distribucije, ki sta hkrati socialno pravični ter okoljsko odgovorni in

- zagotavljanje primerne kakovosti življenja in zdravega delovnega okolja za pridelovalce. 
V zadnjih letih so bile izvedene mnoge raziskave, ki v večini dokazujejo (velike) prednosti ekološke pridelave $\mathrm{v}$ primerjavi s konvencionalno (in tudi integrirano), tako $\mathrm{z}$ vidika vplivov na okolje, biotsko raznovrstnost, podnebne spremembe kot tudi same kakovosti pridelanih živil (Podmenik, 2012).

Razvoj ekološkega kmetijstva v (zahodni) Evropi lahko razdelimo na tri glavna obdobja (Tate, 1994):

- obdobje 1924-1970 zaznamujejo finančne težave in borba za utemeljevanje ekološkega kmetijstva zaradi odklonilnega in tudi sovražnega odnosa okolja; v tem obdobju so bila napisana tudi temeljna dela;

- obdobje 1970-1980, ko začne naraščati okoljska zavest, vzporedno z njo tudi povpraševanje po ekoloških pridelkih oziroma izdelkih, vzpostavijo se glavne simbolne sheme ekološkega kmetijstva in

- obdobje po letu 1980, ko dobi ekološko kmetijstvo širše priznanje in veljavo, vzpostavijo se nacionalni in mednarodni standardi.

Pravi razcvet je ekološko kmetijstvo v Evropi doživelo v devetdesetih letih prejšnjega stoletja, saj je samo v obdobju 1985-1999 število ekoloških kmetij naraslo od 6300 na skoraj 130.000 s 3,3 mio. ha obdelovalnih površin (Padel, 2001). Rast ekološkega kmetijstva se je nadaljevala tudi v novem tisočletju in v letu 2011 je bilo v Evropi registriranih 291.451 ekoloških kmetij, ki so obdelovale dobrih 10 mio. ha površin (Land use in organic ..., 2011).

Razvoj ekološke pridelave oljk se je začel v osemdesetih letih prejšnjega stoletja, predvsem v Franciji, Italiji in Španiji, vendar je ta panoga pridobila na veljavi zlasti v zadnjem desetletju (Santucci, 2007). V zadnjih petnajstih letih beležimo v Evropi stalno rast ekološkega oljkarstva, tako da so ekološki oljčniki v letu 2011 obsegali 423.000 ha, to je 7,5\% vseh oljčnih nasadov v Evropi. Ekološko oljkarstvo je najbolj razširjeno v Španiji (168.619 ha) in Italiji (141.568 ha). Primerjava z ostalimi kulturami ekološkega kmetijstva pokaže, da je obseg oljčnikov na drugem mestu za žiti (1,7 mio. ha), v kategoriji trajnih nasadov pa oljčniki po površini daleč prevladujejo (Land use in organic ..., 2011).

Površina zemljišč, vključenih v ekološko kontrolo, narašča tudi v Sloveniji in je v letu 2012 znašala 35.100 ha, kar predstavlja 7,6 \% vseh kmetijskih zemljišč. Skoraj 88 \% vseh ekoloških zemljišč predstavlja travinje, $8 \%$ njive in dobre $4 \%$ trajni nasadi (Evidenca pridelovalcev in ..., 2012; Analiza stanja ..., 2012).

V Slovenski Istri, kjer se nahajajo praktično vsi (ekološki) oljčniki, v zadnjih letih pridobiva na pomenu ekološko oljkarstvo, ki ga v nadaljevanju podrobneje obravnavamo. Omeniti velja, da so se s pridelavo oljk pri nas ukvarjali številni avtorji (Adamič, 1998; Ogrin, 2002; Podgornik in sod., 2006; Bandelj Mavsar in sod., 2008; Majer, 2009) in je dobro raziskana z različnih vidikov, vendar pa ekološka pridelava do sedaj ni bila deležna večje pozornosti oziroma obravnave.

Naš prispevek predstavlja prvo temeljito raziskavo stanja in značilnosti ekološke pridelave oljk pri nas. V prvem delu predstavljamo razvoj ekološke pridelave oljk v Sloveniji ter ključne razloge oziroma dejavnike za rast te panoge. Sledi podrobnejša prostorska analiza ekološke pridelave oljk po občinah in naseljih Slovenske Istre. V nadaljevanju obravnavamo različne vidike oziroma značilnosti te dejavnosti, od velikosti kmetij, 
količinske pridelave, donosov, trženja, kmetijskih praks do socio-ekonomskih značilnosti kmetij. V sklepnem delu podajamo pogled na prihodnost ter izpostavljamo kritična vprašanja in dileme, povezane z razvojem ekološkega oljkarstva.

\section{METODOLOGIJA}

Prispevek temelji na poglobljenem pregledu in analizi sekundarnih statističnih podatkov ter izvedeni kvalitativni terenski raziskavi. Primarni sekundarni vir predstavljajo podatki Ministrstva za kmetijstvo in okolje (MKO) o številu ekoloških kmetij, strukturi rabe kmetijskih zemljišč, kulturah in pridelkih ekoloških kmetij (Evidenca pridelovalcev in ..., 2012). Na podlagi teh podatkov smo analizirali in ovrednotili stanje, trende ter prostorske značilnosti ekološke pridelave oljk. Pri prostorski analizi in izračunu deleža ekoloških oljčnikov (v primerjavi z vsemi oljčniki) smo uporabili tudi podatke Evidence dejanske rabe kmetijskih in gozdnih zemljišč (2013). Ti podatki so zanesljivejši od uradnih, saj veliko (manjših) oljčnih nasadov ni prijavljenih v register kmetijskih zemljǐ̌č, o čemer so že poročali tudi Bandelj Mavsar in sod. (2008). Prostorske podatke smo s pomočjo programa ARC GIS tudi kartografsko prikazali.

Kvalitativne podatke smo pridobili s terensko raziskavo v letu 2009, v okviru katere smo opravili neposredne intervjuje s 34 pridelovalci oljk, vključenimi v kontrolo ekološkega kmetijstva na območju Slovenske Istre. Izsledki raziskave o značilnostih celotnega ekološkega kmetijstva v Slovenski Istri so bili predhodno že predstavljeni (Podmenik, 2012). Zato smo se v prispevku osredotočili izključno na podrobnejšo analizo in predstavitev razmer na področju pridelave oljk, ki do sedaj še ni bila objavljena. V okviru raziskave smo izvedli polstrukturirane intervjuje, s katerimi smo poskušali čim širše zajeti značilnosti in različne pridelovalne in socio-ekonomske vidike ekološke pridelave oljk. Poudarek je bil na velikosti kmetij (in posameznih parcel), pridelovalnih in tržnih značilnostih, količini pridelka, razlogih za vključitev v ekološko kmetijstvo, izobrazbi pridelovalcev, starostni strukturi na kmetijah, glavnih problemih oziroma ovirah, s katerimi se pridelovalci soočajo, in njihovih načrtih za prihodnost.

\section{PREGLED RAZVOJA EKOLOŠKE PRIDELAVE OLJK}

Zanimanje za ekološko pridelavo oljk se $\mathrm{v}$ Sloveniji iz leta $\mathrm{v}$ letu povečuje, saj se je obseg oljčnikov, vključenih v ekološko kontrolo, povečal iz slabih 5 ha v letu 2004 na kar 184,5 ha v letu 2012. Do leta 2008 so bila sicer zabeležena nihanja v obsegu oljčnikov v ekološki kontroli, ki pa so se umirila in zadnja štiri leta beležimo konstantno rast te panoge. Več kot polovica oljčnikov, vključenih v kontrolo, je tako danes $\mathrm{v}$ fazi preusmerjanja (Evidenca pridelovalcev in ..., 2012). Po uradnih podatkih so se prvi oljkarji začeli vključevati v ekološko kontrolo v letu 2004, vendar pa lahko glede na opravljene pogovore z ekološkimi pridelovalci ugotovimo, da so nekateri že pred tem pridelovali oljke po ekoloških standardih.

Oljčniki predstavljajo $0,5 \%$ vseh ekoloških kmetijskih zemljišč v Sloveniji in dobrih $10 \%$ znotraj kategorije ekoloških trajnih nasadov (sadovnjaki, vinogradi in 
oljčniki). Tukaj velja omeniti, da so v letu 2007 oljčniki predstavljali le dobra $2 \%$ vseh ekoloških trajnih nasadov. V obdobju 2007-2012 se je obseg sadovnjakov povečal za slabih $50 \%$, vinogradov za $150 \%$ in oljčnikov za $760 \%$, kar kaže, da je oljkarstvo res v velikem vzponu (Analiza stanja ..., 2012).

V Sloveniji se je z ekološkim oljkarstvom leta 2012 ukvarjalo 138 kmetij, ki se skoraj vse nahajajo v Slovenski Istri (občine Piran, Izola in Koper). V tej (mezo)regiji ima oljkarstvo znotraj ekološkega kmetijstva ključno vlogo, saj se s to panogo ukvarja več kot 80 \% ekoloških kmetij. Več kot polovica ekoloških kmetij pa je (pretežno) usmerjenih v oljkarstvo, saj jim oljčniki predstavljajo $50 \%$ ali več vseh kmetijskih zemljišč.

V strukturi rabe ekoloških zemljišč predstavljajo oljčniki skoraj 28 \% vseh zemljišč, a se deleži med občinami precej razlikujejo. V občini Koper, kjer je največ ekoloških zemljišč (502,4 ha), predstavljajo ekološki oljčniki petino vseh kmetijskih zemljišč. V občini Izola (85,7 ha ekoloških zemljišč) je njihov delež že skoraj 43 \% (36,5 ha), v občini Piran, kjer je najmanj ekoloških kmetijskih zemljišč, pa oljčniki predstavljajo kar 60,6 \% (Evidenca pridelovalcev in ..., 2012). Upoštevajoč te podatke je očitno, da ekološko oljkarstvo prevzema vse pomembnejšo vlogo v regiji.

Slika 1: Struktura ekološko obdelanih kmetijskih zemljišč po občinah v Slovenski Istri Figure 1: Organic agricultural land by municipalities in Slovenian Istria

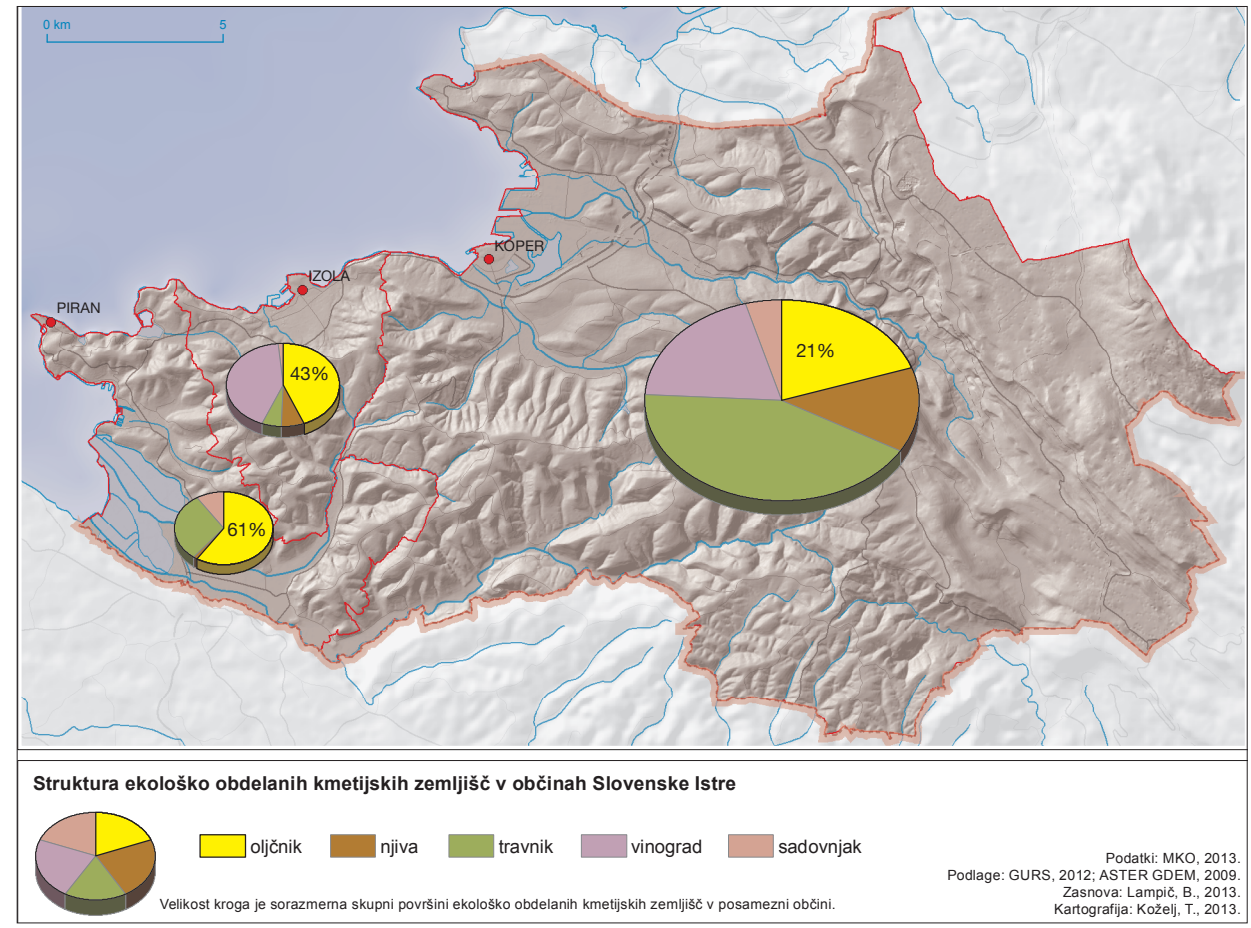


Razloge za hiter razvoj ekološke pridelave oljk lahko iščemo v kombinaciji različnih dejavnikov, med katerimi je najpomembnejše dejstvo, da za razliko od nekaterih drugih kmetijskih panog (npr. zelenjadarstvo ali sadjarstvo), preusmeritev v ekološko pridelavo oljk predvsem ekstenzivnim oziroma manj intenzivnim kmetijam (danes) ne predstavlja večjih tveganj (Parra López, Calatrava Requena, 2005).

Poleg možnosti pozebe je glavna nevarnost za oljkarje v Slovenski Istri oljčna muha (Bactrocera oleae). Ta je bila tudi razlog, da se mnogo pridelovalcev zaradi manj učinkovitih zaščitnih sredstev (v ekološki kmetijstvu) in posledično dodatnega tveganja ni odločalo za preusmeritev v ekološko pridelavo. Od leta 2009 pa je tudi ekološkim pridelovalcem na voljo učinkovito sredstvo GF-120 proti oljčni muhi, izdelano na osnovi naravnega insekticida spinosad, kar je pomembno vplivalo na povečano zanimanje za ekološko oljkarstvo. Omenjeno sredstvo je po Bjeliš in Radunić (2009) tudi učinkovito v boju proti drugemu pomembnemu škodljivcu - oljčnemu molju (Prays oleae). Na povečano zanimanje je vplivala tudi naraščajoča ponudba cenovno dostopnih ekoloških gnojil in drugih sredstev, ki so sedaj na voljo ekološkim oljkarjem.

Zaradi majhnosti območja, poznanstev med pridelovalci in hitrega pretoka informacij se je veliko pridelovalcev odločilo za preusmeritev po načelu 'zgled vleče'. Predvsem zaradi premajhne strokovno-tehnične podpore, ki bi oljkarjem nudila ustrezno pomoč in 'odskočno desko' za preusmeritev v ekološko kmetijstvo, jih je veliko čakalo na izkušnje sosedov, znancev ali drugih oljkarjev, ki so se predhodno že odločili za ekološko pridelavo. Njihove pozitivne izkušnje so tudi bolj negotovim kmetom dale pozitiven signal, da je ekološka pridelava oljk možna, pa tudi uspešna in donosna. Preusmeritev nekaterih uveljavljenih oljkarjev, ki na domačih in tujih tekmovanjih prejemajo najvišja priznanja, v ekološko pridelavo lahko označimo kot dodaten stimulativni dejavnik.

Izpostaviti velja tudi ekonomske motive, saj mnogi kmetje v ekološki pridelavi vidijo možnost boljše prodaje pridelka in hkrati (za še) višjo prodajno ceno olja. Rezultati raziskave so tudi pokazali, da so hektarski donosi primerljivi s tistimi v konvencionalni oziroma integrirani pridelavi. Dodati velja še relativno visoke finančne subvencije, ki za ekološko pridelavo oljk znašajo 555 EUR/ha oziroma 754 EUR/ha v fazi preusmerjanja. Pridelovalci lahko tako v kombinaciji z ukrepom KOP (Kmetijsko-okoljski program) Pridelava avtohtonih in tradicionalnih sort kmetijskih rastlin (velja za sorte istrska belica, buga, črnica in štorta), regionalnimi plačili in plačili za OMD (območja z omejenimi možnostmi za kmetijsko dejavnost; velika večina oljčnikov je na območju z omejitvenimi dejavniki) skupno prejmejo okoli 1150 EUR/ha oziroma 1350 EUR/ ha na leto. Med razloge za povečano zanimanje za ekološko pridelavo lahko uvrstimo tudi napovedano ukinjanje integrirane pridelave, v katero je vključenih veliko število oljkarjev (Integrirana pridelava po letu 2014, 2013).

Omeniti velja še vlogo podpornih organizacij pri razvoju ekološkega kmetijstva v Slovenski Istri. V letu 2009 in 2010 je Združenje ekoloških kmetov Obala (ZEK Obala) skupaj s partnerji uspešno izpeljalo projekt Strategija razvoja ekološkega kmetijstva za Slovensko Istro (LAS Istra, program LEADER). Poleg razvoja ekološkega kmetijstva v Slovenski Istri je bil eden od glavnih ciljev tega projekta tudi (dodatno) 
izobraževanje, informiranje in ozaveščanje pridelovalcev o ekološkem kmetijstvu. V ta namen je bilo izvedenih več delavnic in predavanj. V organizaciji ZEK Obala je bilo izpeljanih še več drugih aktivnosti, neposredno povezanih z ekološko pridelavo oljk in tržnim povezovanjem oljkarjev. Na področju spodbujanja ekološkega oljkarstva in povezovanja oljkarjev je v zadnjih letih aktivno tudi Društvo oljkarjev Slovenske Istre (DOSI), v okviru katerega so v letu 2013 ustanovili Društvo ekoloških oljkarjev Istre.

Delo območne kmetijske svetovalne službe je bilo v preteklosti usmerjeno v promocijo integrirane pridelave, ekološki pridelavi pa praktično niso posvečali pozornosti (Podmenik, 2012). Premik se je zgodil predvsem ob izvajanju čezmejnega projekta Zmanjšanje onesnaževanja in ohranjanje biotske pestrosti v kmetijstvu s poudarkom na oljkarstvu, pri katerem je imela svetovalna služba nosilno vlogo. V zadnjih treh letih tako tudi kmetijska svetovalna služba s svojim delom aktivneje prispeva k promociji in razvoju ekološke pridelave oljk.

Seveda pa je na razvoj ekološke pridelave oljk pomembno vplivala tudi (splošna) popularizacija ekološkega kmetijstva v Sloveniji. Posledica tega je večja ozaveščenost (potrošnikov in pridelovalcev) in tudi naraščajoče povpraševanje po ekološko pridelanih živilih.

\section{PROSTORSKA ANALIZA EKOLOŠKE PRIDELAVE OLJK}

V letu 2012 je bilo v občini Koper 104 ha oljčnikov, v občini Piran 40 ha in v občini Izola 36 ha. Podrobnejša prostorska analiza po naseljih je pokazala, da se od skupaj 125 naselij v Slovenski Istri, oljčniki nahajajo v 108 naseljih, ekološka pridelava oljk pa je prisotna v 55 naseljih. Daleč največ ekoloških oljčnikov, 21 ha oziroma dobro desetino vseh, obdelujejo v Krkavčah. Sledijo Zgornje Škofije $(9,4$ ha) ter naselja Šared, Jagodje, Baredi in Lucija, kjer obdelujejo od 7 do 9 ha ekoloških oljčnikov. Večina ekoloških oljčnikov (okoli 110 ha) se nahaja na dvignjenih legah flišnega gričevja, kjer so tudi najboljši pogoji za (ekološko) gojenje oljk, predvsem z vidika pogostnosti pojavljanja bolezni in škodljivcev. Vendar pa z oddaljenostjo od morja padajo temperature in tako so (vzhodnejša) zaledna območja bolj ranljiva na pojav pozebe. Osp in Gabrovica pri Črnem Kalu sta najvzhodnejši naselji, kjer pridelujejo oljke po standardih ekološkega kmetijstva. V zadnjih dveh letih je zaznati močan trend širjenja ekoloških oljčnikov tudi v nižjih in obmorskih legah (npr. v Sečovljah, Jagodju, Luciji, Strunjanu), kjer je že okoli 65 ha oziroma dobra tretjina vseh oljčnikov v ekološki kontroli (Evidenca pridelovalcev in ..., 2012). Podrobnejši prikaz stanja po naseljih je prikazan v preglednici 1 . 
Preglednica 1: Površina in delež ekoloških oljčnikov po naseljih treh občin v Slovenski Istri Table 1: Area and proportion of organic olive orchards by settlements of three municipalities in Slovenian Istria

\begin{tabular}{|c|c|c|c|c|c|}
\hline Občina & Naselje & $\begin{array}{l}\text { Kmetijska } \\
\text { zemljišča } \\
\text { skupaj (ha) }\end{array}$ & $\begin{array}{l}\text { Delež } \\
\text { oljčnikov (\%) }\end{array}$ & $\begin{array}{l}\text { Površina } \\
\text { ekoloških } \\
\text { oljčnikov (ha) }\end{array}$ & $\begin{array}{l}\text { Delež ekoloških } \\
\text { oljčnikov od vseh } \\
\text { oljčnikov (\%) }\end{array}$ \\
\hline \multirow[t]{8}{*}{ IZOLA } & Baredi & 173,55 & 29,3 & 8,37 & 28,6 \\
\hline & Cetore & 76,06 & 11,9 & 2,05 & 17,3 \\
\hline & Dobrava & 97,66 & 28,8 & 6,09 & 21,1 \\
\hline & Izola & 370,54 & 60,9 & 3,36 & 5,5 \\
\hline & Jagodje & 185,27 & 44,1 & 7,92 & 18,0 \\
\hline & Korte & 196,59 & 58,0 & 3,27 & 5,6 \\
\hline & Malija & 54,30 & 12,6 & 2,45 & 19,5 \\
\hline & Šared & 248,78 & 50,9 & 8,96 & 17,6 \\
\hline \multirow[t]{23}{*}{ KOPER } & Ankaran & 347,12 & 46,7 & 4,60 & 9,9 \\
\hline & Barizoni & 36,92 & 16,3 & 6,72 & 41,3 \\
\hline & Bertoki & 251,74 & 21,1 & 3,36 & 16,0 \\
\hline & Bonini & 231,03 & 31,0 & 0,89 & 2,9 \\
\hline & Boršt & 130,05 & 6,2 & 0,82 & 13,3 \\
\hline & Bošamarin & 106,14 & 12,1 & 0,21 & 1,7 \\
\hline & Čežarji & 54,74 & 13,5 & 0,40 & 2,9 \\
\hline & Dekani & 206,48 & 44,3 & 2,90 & 6,5 \\
\hline & Dilici & 52,69 & 3,1 & 0,29 & 9,3 \\
\hline & $\begin{array}{l}\text { Gabrovica pri Črnem } \\
\text { Kalu }\end{array}$ & 28,86 & 7,8 & 0,94 & 12,0 \\
\hline & Gažon & 100,03 & 27,7 & 2,57 & 9,3 \\
\hline & Grinjan & 35,17 & 10,6 & 0,21 & 1,9 \\
\hline & Grintovec & 123,28 & 33,6 & 5,19 & 15,5 \\
\hline & Hrvatini & 73,09 & 19,9 & 0,02 & 0,1 \\
\hline & Kampel & 95,90 & 15,4 & 0,30 & 2,0 \\
\hline & Kolomban & 94,59 & 23,6 & 3,27 & 13,9 \\
\hline & Koper & 389,94 & 77,2 & 4,94 & 6,4 \\
\hline & Koštabona & 139,42 & 23,3 & 4,04 & 17,3 \\
\hline & Krkavče & 291,82 & 75,3 & 21,16 & 28,1 \\
\hline & Labor & 137,71 & 6,7 & 0,90 & 13,4 \\
\hline & Marezige & 206,36 & 30,1 & 3,47 & 11,5 \\
\hline & Montinjan & 49,70 & 7,4 & 0,36 & 4,8 \\
\hline & Osp & 167,69 & 10,5 & 3,01 & 28,6 \\
\hline
\end{tabular}




\begin{tabular}{|c|c|c|c|c|c|}
\hline Občina & Naselje & $\begin{array}{l}\text { Kmetijska } \\
\text { zemljišča } \\
\text { skupaj (ha) }\end{array}$ & $\begin{array}{l}\text { Delež } \\
\text { oljčnikov (\%) }\end{array}$ & $\begin{array}{l}\text { Površina } \\
\text { ekoloških } \\
\text { oljčnikov (ha) }\end{array}$ & $\begin{array}{l}\text { Delež ekoloških } \\
\text { oljčnikov od vseh } \\
\text { oljčnikov (\%) }\end{array}$ \\
\hline \multirow[t]{14}{*}{ KOPER } & Pomjan & 92,64 & 3,3 & 0,14 & 4,2 \\
\hline & Puče & 174,84 & 25,9 & 3,18 & 12,3 \\
\hline & Spodnje Škofije & 206,84 & 36,5 & 3,08 & 8,4 \\
\hline & Srgaši & 64,48 & 15,4 & 2,14 & 13,9 \\
\hline & Stepani & 36,55 & 1,4 & 0,26 & 19,3 \\
\hline & Sv. Anton & 270,47 & 45,4 & 0,41 & 0,9 \\
\hline & Šalara & 143,00 & 26,5 & 2,84 & 10,7 \\
\hline & Šmarje & 103,99 & 28,2 & 0,54 & 1,9 \\
\hline & Tinjan & 76,22 & 8,6 & 0,24 & 2,8 \\
\hline & Triban & 142,83 & 11,7 & 0,47 & 4,0 \\
\hline & Truške & 91,45 & 3,9 & 1,81 & 45,8 \\
\hline & Zabavlje & 57,66 & 2,7 & 0,94 & 35,3 \\
\hline & Zgornje Škofije & 79,06 & 26,5 & 9,47 & 35,7 \\
\hline & Župančiči & 86,61 & 5,9 & 0,46 & 7,8 \\
\hline \multirow[t]{10}{*}{ PIRAN } & Dragonja & 249,05 & 22,0 & 1,62 & 7,3 \\
\hline & Lucija & 197,42 & 65,1 & 7,81 & 12,0 \\
\hline & $\begin{array}{l}\text { Nova vas nad } \\
\text { Dragonjo }\end{array}$ & 112,38 & 33,0 & 5,70 & 17,3 \\
\hline & Padna & 98,83 & 38,5 & 4,59 & 11,9 \\
\hline & Parecag & 197,71 & 71,3 & 4,14 & 5,8 \\
\hline & Portorož & 72,42 & 18,5 & 1,19 & 6,4 \\
\hline & Seča & 175,31 & 69,3 & 3,46 & 5,0 \\
\hline & Sečovlje & 441,73 & 27,0 & 5,97 & 22,1 \\
\hline & Strunjan & 156,48 & 55,3 & 5,01 & 9,1 \\
\hline & Sv. Peter & 146,32 & 56,3 & 6,26 & 11,1 \\
\hline
\end{tabular}

Vira/Sources: Evidenca dejanske rabe ..., 2013; Evidenca pridelovalcev in ..., 2012

Če primerjamo delež ekoloških oljčnikov med vsemi oljčniki (slika 2), je ekološka pridelava oljk najbolj razvita v Truškah, Barizonih, Zgornjih Škofijah in Zabavljah. V devetih naseljih delež ekoloških oljčnikov presega $20 \%$ in to lahko označimo za visoko stopnjo. V razred z 10-20 \% ekoloških oljčnikov se uvršča 20 naselij, v 13 naseljih pa je ta delež nižji od $5 \%$, kar lahko opredelimo kot šibko prisotnost ekološke pridelave oljk. V 53 naseljih v Slovenski Istri, kjer se pojavljajo oljčniki, ekološka pridelava ni prisotna (Evidenca dejanske rabe ..., 2013; Evidenca pridelovalcev in ..., 2012). 
Slika 2: Delež oljčnikov, vključenih v kontrolo ekološkega kmetijstva, po naseljih na območju Slovenske Istre (v \%)

Figure 2: Share of organic olive orchards by settlements in Slovenian Istria (in \%)

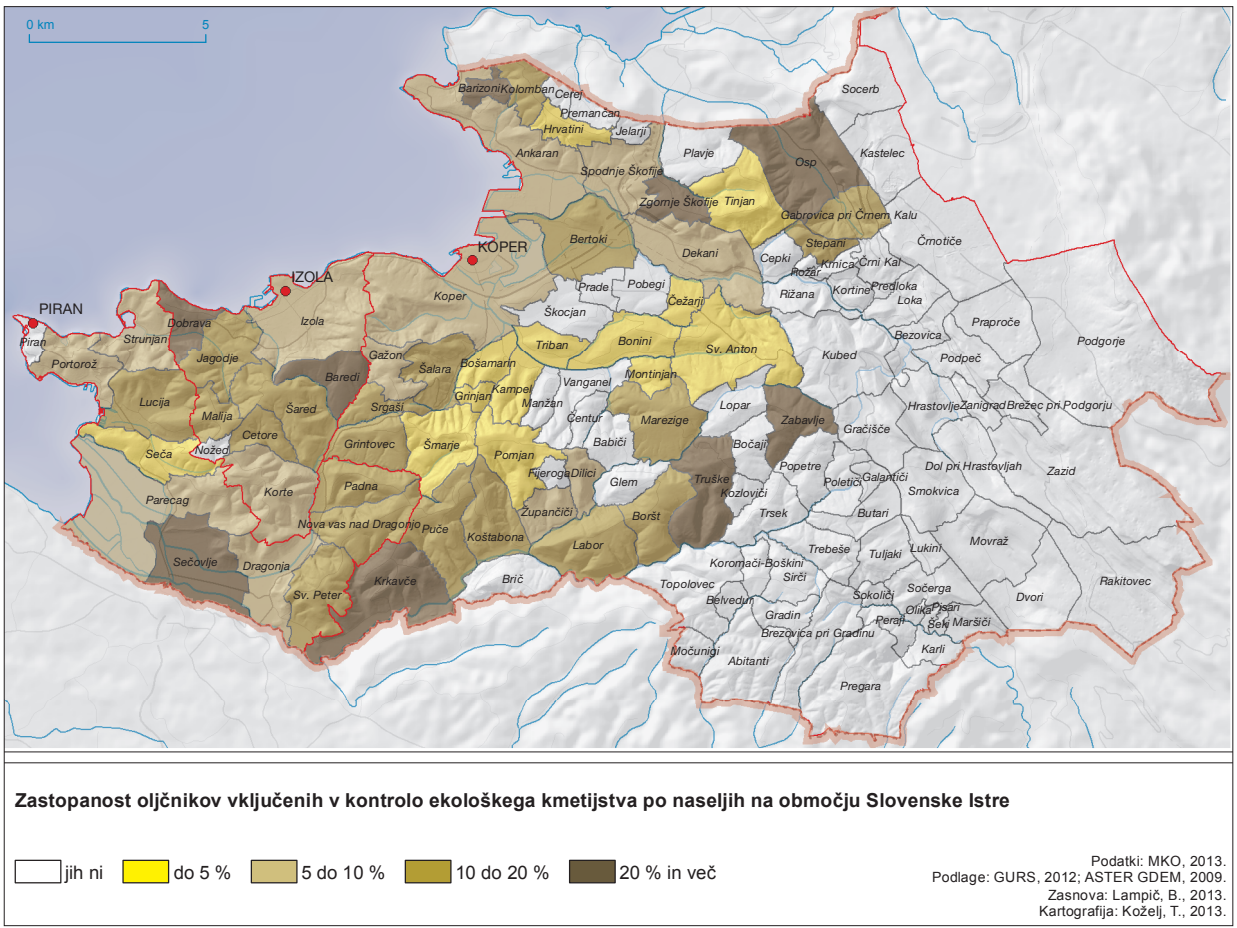

\section{ZNAČILNOSTI EKOLOŠKE PRIDELAVE OLJK}

Čeprav je oljkarstvo daleč najbolj pomembna kmetijska panoga na ekoloških kmetijah v Slovenski Istri, pa ekološki oljčniki obsegajo nekaj manj kot $30 \%$ vseh površin v ekološki kontroli. Takšno nesorazmerje je posledica dejstva, da so oljkarsko usmerjene kmetije v povprečju (veliko) manjše; kmetije v povprečju pridelujejo oljke na 1,3 ha, grozdje pa npr. kar na okoli 6 ha. Podrobnejša analiza velikostne strukture oljkarskih kmetij pokaže, da jih ima največ manj kot 1 ha oljčnikov (51\%), $28 \%$ jih obdeluje $1-2$ ha, $17 \%$ 2-4 ha in le $4 \%$ kmetov ima več kot 4 ha oljčnikov. Pomembno je dejstvo, da skupno $21 \%$ pridelovalcev z oljčniki, večjimi od 2 ha, obdeluje kar $50 \%$ vseh ekoloških nasadov oljk v regiji (Evidenca pridelovalcev in ..., 2012). Vrhovnikova (2005) navaja, da ima kar 90 \% vseh oljkarjev manj kot hektar oljčnikov, kar pomeni, da so ekološke kmetije večje od konvencionalnih oziroma integriranih.

Po podatkih o ekoloških pridelkih je bilo v letu 2012 pridelanih dobrih 225 ton oljk, iz katerih so pridobili okoli 38.000 litrov olja (Evidenca pridelovalcev in ..., 2012). Kmetije praktično ves pridelek oljk predelajo $\mathrm{v}$ olje, le neznaten del porabijo za druge namene 
(vlaganje, namazi ipd.). V letu 2012 je bil pridelek oljk zaradi neugodnih vremenskih razmer (pozeba, suša, toča, burja) opazno nižji kot v letu 2011. Povprečni donos je v letu 2012 znašal $1200 \mathrm{~kg} / \mathrm{ha}$, v letu 2011 pa $1700 \mathrm{~kg} / \mathrm{ha}$. Uradne številke so nekoliko nižje, kot smo ugotovili s terenskim anketiranjem, kjer je povprečni donos znašal $2200 \mathrm{~kg} / \mathrm{ha}$.

Hektarski donosi se opazno razlikujejo med posameznimi pridelovalci in se gibljejo od $300 \mathrm{~kg} / \mathrm{ha}$ do $6000 \mathrm{~kg} / \mathrm{ha}$. Največ pridelovalcev (32\%) je svoje donose ocenilo med 3000 in $4000 \mathrm{~kg} / \mathrm{ha}$, kar je (razmeroma) visok pridelek. Dobro petino je donose ocenilo med 1000 in $2000 \mathrm{~kg} / \mathrm{ha}$, donose od 2000 do $3000 \mathrm{~kg} /$ ha dosega $10 \%$ pridelovalcev, $15 \%$ pa dosega donose nad $4000 \mathrm{~kg} / \mathrm{ha}$. Največji donos znaša $6000 \mathrm{~kg} / \mathrm{ha}$ in smo ga zabeležili pri pridelovalcu, ki je bil v času izvedbe ankete v prvem letu preusmerjanja in je do vpisa v ekološko kontrolo gnojil oljke z mineralnimi gnojili. Pomembno je poudariti, da (opazno) višje donose dosegajo tisti, ki so v ekološko kontrolo vpisani krajši čas. Podmenik (2012) navaja, da po podatkih kmetijske svetovalne službe v Kopru znašajo povprečni donosi za konvencionalne in integrirane oljkarje okoli $2500 \mathrm{~kg} / \mathrm{ha}$. Vendar se tudi tu (podobno kot pri ekološki pridelavi) donosi zelo razlikujejo in se gibljejo od skromnih 1000 do $6000 \mathrm{~kg} / \mathrm{ha}$. Po uradnih statističnih podatkih so povprečni donosi še nižji, saj se gibljejo okoli $2000 \mathrm{~kg} / \mathrm{ha}$ (Pridelava sadja ..., 2013). Zaključimo lahko, da v povprečju ne prihaja do opaznejših razlik v hektarskih donosih med ekološkimi ter konvencionalnimi pridelovalci oljk.

Z donosi so seveda v veliki meri povezane kmetijske prakse na kmetiji. Večina pridelovalcev gnoji oljčnike s kupljenimi gnojili, dovoljenimi v ekološki pridelavi, predvsem s t. i. peleti. Njihove izkušnje s temi gnojili so dobre, nekateri so povedali, da uporaba teh gnojil omogoča zelo hitro rast rastlin z bogatimi plodovi. Poraba tovrstnih gnojil se med pridelovalci zelo razlikuje in se giblje od okoli $300 \mathrm{~kg} / \mathrm{ha}$ do $2000 \mathrm{~kg} / \mathrm{ha}$. Uporabljena gnojila v veliko primerih bazirajo na predelanih živalskih ostankih (npr. roževina, kostna in krvna moka, dlaka), kar po eni strani povečuje njihovo učinkovitost, na drugi strani pa upravičeno sproža dileme o skladnosti tovrstnih gnojil s temelji ekološkega kmetijstva. Le malo pridelovalcev oljčne nasade gnoji (tudi) s hlevskim gnojem oziroma kompostom. Nekateri tudi kombinirajo uporabo hlevskega gnoja in kupljenih gnojil. Rezultati anketiranja so pokazali, da približno četrtina anketirancev oljčnikov ne gnoji, predvsem zato, ker so v ekološko kontrolo vključeni prvo leto in se tako zaradi (izdatnejše) uporabe gnojil v preteklih letih niso odločili za gnojenje.

Okoljsko zelo primerna je paša oziroma reja živali (konji, govedo in ovce) v oljčnih nasadih, ki pa jo izvajajo le na nekaj kmetijah. V povezavi s problematiko gnojenja in ohranjanja rodovitnosti prsti je potrebno dodati, da se premalo oljkarjev poslužuje t. i.'zelenega gnojenja', s katerim bi lahko pokrili del potreb po dušiku. S setvijo lucerne, ki je zaradi odpornosti na sušo ena najbolj primernih metuljnic, lahko po Bavec in sod. (2009a) v tleh akumuliramo do $285 \mathrm{~kg}$ zračnega dušika na hektar. Opozoriti velja še, da kar nekaj oljkarjev nima zatravljenih nasadov, kar bi po našem mnenju morala biti 'osnovna' praksa v vseh ekoloških oljčnikih, tako s stališča varovanja okolja, biotske raznovrstnosti kot tudi manjše porabe energije in posledično izpustov toplogrednih plinov. Oljkarji namenjajo premalo pozornosti tudi skrbi za večjo pestrost pridelave, kar bi moral biti eden glavnih ciljev. V preteklosti je bila na tem območju zelo razširjena praksa mešanih kultur v nasadih (cultura 
mista), ki bi jo veljalo z vidika ekološke pridelave ponovno obuditi. Pridelavo oljk je mogoče uspešno združiti z gojenjem tradicionalnih sadnih sort, vrtnin, zelišč in poljščin.

Ekološki oljkarji so kot najbolj pereče probleme izpostavili vedno bolj neugodne vremenske pogoje. Izpostavili so predvsem sušo, ki je bila še posebej pereča v letu 2012, in pomanjkanje možnosti za namakanje oziroma zalivanje. Sledijo problemi, povezani s pojavom škodljivcev in bolezni. Glavno nevarnost predstavlja oljčna muha, ki lahko v veliki meri vpliva na zmanjšanje pridelka in kvaliteto olja. Pojav oljčne muhe je sicer vezan predvsem na 'ugodne' vremenske razmere za njen razvoj ter tudi na lego nasadov, saj se najpogosteje pojavlja v nižjih in vlažnejših obmorskih legah (Podgornik in sod., 2006). Oljkarjem so na voljo različna dovoljena sredstva proti temu škodljivcu (Bavec in sod., 2009a), predvsem sredstvo GF-120, ki ga oljkarji najpogosteje uporabljajo v boju proti oljčni muhi in se lahko po učinkovitosti primerja tudi s 'konvencionalnimi' insekticidi (Sameh in sod., 2009; Gonçalves, Santos, 2012). V veliko primerih to sredstvo kombinirajo z uporabo vab, ki so hkrati tudi pokazatelj ogroženosti. Nekaj pridelovalcev je izpostavilo probleme pomanjkanja delovne sile in lastnega časa za delo ter dostopa do informacij oziroma znanj o ekološki pridelavi. Dva pridelovalca sta ‘samokritično’ poudarila, da je ekološka kontrola premalo stroga.

Starostna struktura članov anketiranih kmetij je relativno ugodna. Kot najbolj vitalne lahko opredelimo kmetije z dvema generacijama (0-19 let ter 20-59 let), ki jih je osem oziroma slaba petina, in kmetije s tremi generacijami (0-19 let, 20-59 let, 60 in več let), ki jih je devet oziroma četrtina. Devet je tudi kmetij z 'zrelim tipom gospodinjstva', na katerih prebivajo člani stari od 20 do 59 let. Osem kmetij smo uvrstili v tip 'starajoče se' kmetije z dvema generacijama (20-59 let ter 60 in več let). Le dve kmetiji se uvrščata v tip 'ostarele' kmetije s člani, starimi 60 in več let.

Presenetljiva je izjemno visoka izobrazbena struktura pridelovalcev, saj jih ima kar 40 \% zaključeno višjo šolo in kar dobra četrtina visoko šolo ali fakulteto. Enak delež je tudi takih s končano štiriletno srednjo šolo. Niti en pridelovalec nima končane le osnovne šole. Večina nima kmetijske izobrazbe, kar po našem mnenju ne predstavlja ovire, nasprotno, za ekološko kmetijstvo je splošno znano, da pridelovalci pogosto prihajajo iz različnih (nekmetijskih) strok.

Socio-ekonomska slika oljkarskih družinskih kmetij je pokazala, da samo dve kmetiji ustvarjata prihodke izključno s kmetijstvom. Ena je po usmeritvi mešana (vinogradništvo, zelenjadarstvo in sadjarstvo), druga pa je izključno oljkarska kmetija. Na četrtini kmetij se s kmetijstvom preživlja polovica družinskih članov. Prevladujejo kmetije (70 \%), ki jim prihodek iz kmetijstva pomeni le dodatni zaslužek, poleg zaposlitve ali pokojnine. Kljub temu je velika večina kmetij tržno usmerjenih, saj svojih pridelkov ne trži le dobrih 15 \% kmetij. To so kmetije, ki imajo le okoli 0,5 ha oljčnikov ali pa nasadi še niso v obdobju rodnosti.

Zanimiv je tudi vpogled $v$ način trženja, kjer se kaže velika odvisnost od prodaje na domu, saj skoraj polovici kmetij prestavlja edini način trženja oljčnega olja. Četrtina kmetij dopolnjuje prodajo na domu z drugimi prodajnimi potmi (tržnica, sejmi ipd.). Nekaj pridelovalcev trži svoje olje tudi v (specializiranih) trgovinah, eden ga tudi izvaža v Nemčijo.

Cene oljčnega olja se opazno razlikujejo glede na status kmetije (kmetija še v preusmeritvi ali že s pridobljenim ekološkim certifikatom), glede na prodajno pot, tržno prepoznavnost, uveljavljenost in kvaliteto olja (npr. pridobljena oznaka 'geografsko 
poreklo'). Prodajne cene se gibljejo med 10 in 20 EUR za liter, pri nekaterih pridelovalcih pa so še višje. Te cene so precej višje od cene tujih ekoloških oljčnih olj, ki se prodajajo v supermarketih in specializiranih trgovinah pri nas (Podmenik, 2012).

Večina kmetij ima že lastne blagovne znamke, kar kaže na prisotnost 'podjetniškega duha' med oljkarji. Manj prisotno je (tržno) sodelovanje in povezovanje med ekološkimi pridelovalci, kar bi bilo pomembno z vidika (potencialnega) skupnega nastopanja na trgu. S tem namenom je bila v okviru oljkarskega društva DOSI, ki združuje okoli 450 oljkarjev, ustanovljena tudi skupina proizvajalcev ekstra deviškega oljčnega olja Slovenske Istre z zaščiteno označbo porekla - EDOOSI ZOP (Društvo oljkarjev Slovenske Istre (DOSI), 2013), vendar pa pod to znamko ne tržijo ekološko pridelanega olja.

Kot ključni motiv za vključitev v ekološko kmetijstvo so oljkarji največkrat navajali skrb za okolje ter da so kmetovali v skladu s praksami ekološke pridelave, še preden so se vključili v kontrolo. Zlasti slednje je nekoliko vprašljivo, saj je večina oljkarjev pred vključitvijo v kontrolo uporabljala sredstva, ki v ekološki pridelavi niso dovoljena. Slaba tretjina jih je kot razlog navedla ekonomske motive, pri petih je bil to izključni motiv. Intervjuji so pokazali, da so ekonomski motivi pomembnejši pri pridelovalcih, ki so se v ekološko kmetijstvo vključili šele v zadnjih treh letih, v primerjavi s tistimi, ki so v kontroli že dalj časa (pet let in več). V veliko primerih igrajo ekonomski motivi pomembnejšo vlogo kot to navajajo kmetovalci (Udovč, 2001; Podmenik, 2012), kar po naši oceni velja tudi v primeru ekoloških oljkarjev.

\section{PRIHODNOST EKOLOŠKEGA OLJKARSTVA IN KRITIČ- NI POGLED NA PRAKSE OLJKARJEV}

Kljub opisani hitri rasti ekološke pridelave oljk pa ostaja še veliko možnosti za nadaljnji razvoj te kmetijske panoge, saj oljčniki, ki so vključeni v kontrolo ekološkega kmetijstva, obsegajo komaj dobrih $10 \%$ vseh oljčnih nasadov pri nas (Analiza stanja ..., 2012). Prostorska analiza je tudi pokazala, da v kar 53 naseljih z oljčnimi nasadi ekološko oljkarstvo še ni prisotno; večinoma so to naselja v vzhodnejših delih zaledja. Prav tako je v 26 naseljih delež ekoloških oljčnikov nižji od $10 \%$. Glede na dosedanje trende ocenjujemo, da bi se lahko do leta 2015 površina ekoloških oljčnikov povečala na 300 do 350 ha, torej na okoli 20 \% vseh oljčnikov v Sloveniji. S tem bi Slovenija postala vodilna država v Evropi po deležu ekoloških oljčnikov.

$\mathrm{Na}$ nadaljnjo rast bo pomembno vplivala tudi ukinitev integrirane pridelave sadja oziroma oljk, ki se napoveduje z novim Programom razvoja podeželja (Integrirana pridelava po letu 2014, 2013). Dodati je treba, da so veljavne finančne spodbude za preusmeritev v ekološko pridelavo oljk, razmeroma dobro postavljene, za razliko od nekaterih drugih panog (npr. pridelava zelenjave). To kaže tudi primerjava z drugimi evropskimi državami, saj smo v samem vrhu po zneskih subvencij za ekološko pridelavo oljk (Analiza stanja ..., 2012; Schwarz, Nieberg, Sanders, 2010).

Pričakujemo lahko nadaljnjo popularizacijo ekološkega kmetijstva in naraščanje povpraševanja po (domačih) ekološko pridelanih živilih, kar bo vplivalo tudi na razvoj 
ekološkega oljkarstva. Raziskave kažejo, da si slovenski kupci želijo kupovati domača in lokalno pridelana ekološka živila in le tem dajejo prednost pred uvoženimi (Slabe, Lampič, Juvančič, 2011). Glede na podatek, da v Sloveniji v povprečju porabimo manj kot liter oljčnega olja na leto na prebivalca (Oljčno olje, 2012), bo nujno potrebno okrepiti promocijske aktivnosti in dodatno ozaveščnje javnosti tako s strani pridelovalcev kot drugih akterjev. Domače povpraševanje bo v prihodnje odvisno tudi od cen in dostopnosti ekološko pridelanih olj, zato bo povezovanje in skupno trženje ekoloških oljkarjev vse pomembnejše. Glede na trenutne ekonomske razmere v državi in razmeroma visoke cene domačih (ekoloških) oljčnih olj se bodo oljkarji verjetno primorani cenovno prilagoditi danim razmeram. Določene možnosti so tudi v izvozu, kar pa je povezano z večjimi promocijskimi stroški in zagotavljanjem (pre)velikih količin.

Potrebno je izpostaviti še eno ključno vprašanje: v kolikšni meri prakse ekoloških oljkarjev sledijo temeljnim načelom ekološke pridelave? Že dejstvo, da so kmetije v veliki večini (strogo) monokulturo usmerjene in brez živine, ni v skladu z zgoraj navedenimi načeli ekološkega kmetijstva.

Na osnovi rezultatov raziskave ugotavljamo, da velik delež oljkarjev ne sledi opisanim dobrim praksam sonaravnega kmetovanja. Tako lahko na primeru ekološke pridelave oljk v Sloveniji govorimo o (delni) ‘konvencionalizaciji’ ekološkega kmetijstva, ki predstavlja odklon od vrednot in temeljev ekološkega kmetovanja ter približevanje konvencionalnemu kmetijstvu. Problem 'konvencionalizacije ekološkega kmetijstva' je že nekaj let prisoten tudi v drugih evropskih državah (Darnhofer in sod., 2010) in predstavlja enega ključnih izzivov, s katerimi se srečuje ekološko kmetijstvo.

Da bi uspešneje dosegali temeljne cilje ekološke pridelave, ki presegajo zgolj upoštevanje obstoječih (minimalnih) uradnih tehničnih standardov, bi bilo potrebno v prihodnje več pozornosti nameniti strokovni podpori ter (dodatnemu) ozaveščanju in izobraževanju pridelovalcev oljk. To bi bilo zelo pomembno tako z vidika varovanja okolja, kot tudi ohranjanja verodostojnosti ekološkega kmetijstva pred širšo javnostjo in potrošniki.

\section{Viri in literatura}

Adamič, F., 1998. Stanje in razvoj južnih kultur in oljkarstva v slovenski Istri. Pregled raziskav oljke in oljčnega olja v obdobju 1945-1995. Glasnik Znanstveno-raziskovalnega središča Univerze na Primorskem, 5, str. 22-26.

Analiza stanja ekološkega kmetovanja, 2012. Ministrstvo za kmetijstvo in okolje. URL: http://www.mko.gov.si/si/delovna_podrocja/kmetijstvo/ekolosko_kmetovanje/analiza_stanja_ekoloskega_kmetovanja (Citirano 20.6. 2012).

Bandelj Mavsar, D., Bučar-Miklavčič, M., Mihelič, R., Podgornik, M., Raffin, G., Režek Donev, N., Valenčič, V., 2008. Sonaravno ravnanje z ostanki predelave oljk. Koper, Znanstveno-raziskovalno središče Univerze na Primorskem, Založba Annales, 100 str.

Bavec, M., 2001. Ekološko kmetijstvo. Ljubljana, Založba Kmečki glas, 448 str.

Bavec, M., Robačer, M., Repič, P., Štabuc-Starčevič, D., 2009a. Sredstva in smernice za ekološko kmetijstvo. Maribor, Fakulteta za kmetijstvo in biosistemske vede, Inštitut za ekološko kmetijstvo, 149 str. 
Bavec, M., Grobelnik Mlakar, S., Rozman, Č., Pažek, K., Bavec, F., 2009b. Sustainable agriculture based on integrated and organic guidelines: understanding terms. The case of Slovenian development and strategy. Outlook on agriculture, 38, 1, str. 89-95.

Beaufoy, G., 2001. The environmental impact of olive oil production in the European Union: practical options for improving the environmental impact, 73 str. URL: http:// ec.europa.eu/environment/agriculture/pdf/oliveoil.pdf (Citirano 20. 6. 2012).

Bjeliš, M. in Radunić, D., 2009. Control of olive moth - Prays oleae Bernhard (Lepidoptera, Hyponomeutidae) flower generation by insecticide cover sprays. Zbornik predavanj in referatov 9. slovenskega posvetovanja o varstvu rastlin z mednarodno udeležbo, Nova Gorica. URL: http://dvrs.bf.uni-lj.si/spvr/2009/61bjelis_09.pdf (Citirano 18. 6. 2012).

Cunha, S. C., Lehotay, S. J., Mastovska, K., Fernandes, J. O., Oliveira, M. B., 2010. Sample preparation approaches for the analysis of pesticide residues in olives and olive oils. United States Department of Agriculture, Agriculture Research Service, str. 653-666. URL: http://naldc.nal.usda.gov/download/41268/PDF (Citirano 20. 6. 2012).

Darnhofer, I., Lindenthal, T., Bartel-Kratochwil, R., Zollitsch, W., 2010. Conventionalisation of organic farming practices: from structural criteria towards an assessment based on organic principles. Agronomy for sustainable development, 30, 1, str. 67-81. URL: http://www.wiso.boku.ac.at/fileadmin/_H73/H733/pub/Ika/2010_ASD_ConvOF.pdf (Citirano 10. 6. 2012).

Društvo oljkarjev Slovenske Istre (DOSI). 2013. URL: http://www.dosi.si/o-nas/edosi-zop (Citirano 1. 12. 2013).

Evidenca dejanske rabe kmetijskih in gozdnih zemljišč. 2013. Ministrstvo za kmetijstvo in okolje. URL: http://www.mko.gov.si/si/aplikacije_registri_in_obrazci (Citirano 3. 5. 2013).

Evidenca pridelovalcev in predelovalcev ekoloških pridelkov in živil, 2012. Ministrstvo za kmetijstvo in okolje, interna baza MKO (Posredovana 22. 5. 2013).

Gonçalves, M. F., Santos, S. A. P., 2012. Efficacy of spinosad bait sprays to control $B a-$ ctrocera oleae and impact on non-target arthropods. Phytoparasitica, 40, 1, str. 17-28.

Integrirana pridelava po letu 2014. 2013. Ministrstvo za kmetijstvo in okolje. URL: http:// www.arhiv.mkgp.gov.si/si/splosno/vstopna_stran/aktualne_teme (Citirano 1. 12. 2013).

Lampkin, N. H., 1994. Organic farming: sustainable agriculture in practice. V: Lampkin, N. H., Padel, S. (ur.). The economics of organic farming: an international perspective. Wallingford, CAB International, str. 3-9.

Land use in organic agriculture by country and region, 2011. Research Institute of Organic Agriculture (FIBL). URL: http://www.organic-world.net/statistics-data-tables-dynamic.html?\&L=0 (Citirano 20. 6. 2012).

Majer, A., 2009. Topoclimatic conditions as factors, influencing on the olive growing in the municipality of Piran. Annales, Series historia naturalis, 19, 1, str. 105-114.

Ogrin, D., 2002. Pozebe v primorju z vidika uspevanja mediteranskih kultur. Dela, 18, str. $157-170$.

Oljčno olje. 2012. Ministrstvo za kmetijstvo in okolje. URL: http://www.mko.gov.si/si/ delovna_podrocja/kmetijstvo/kmetijski_trgi/oljcno_olje (Citirano 21. 6. 2012). 
Padel, S., 2001. Conversion to organic farming: a typical example of the diffusion of an innovation? Sociologia ruralis, 40, 1, str. 40-61. URL: http://www.supagro.fr/capeye/ public/2nd_pilier/Article_Conversion_AB_Padel_01.pdf (Citirano 10. 6. 2012).

Parra López, C., Calatrava Requena, J., 2005. Factors related to the adoption of organic farming in Spanish olive orchards. Spanish journal of agricultural research, 3, 1, str. 5-16. URL: http://www.inia.es/gcontrec/pub/005-016-\%288905-Factors rela_1161759971234.pdf (Citirano 15. 6. 2012).

Podgornik, M., Bandelj Mavsar, D., Jančar, M., Bučar-Miklavčič, M., 2006. Spremljanje pojava oljčne muhe (Bactrocera oleae L.) v Slovenski Istri v letu 2005 z novo metodo za fitosanitarno varstvo oljk. Annales, Series historia naturalis, 16, 2, str. 223-230.

Podmenik, D., 2012. Trendi in perspektive ekološkega kmetijstva s poudarkom na Sloveniji in Slovenski Istri. Ljubljana, Založba Vega, 284 str.

Pridelava sadja v intenzivnih sadovnjakih in oljk v intenzivnih oljčnikih. 2013. Statistični urad Republike Slovenije. URL: http://pxweb.stat.si/pxweb/Database/Okolje/15_kmetijstvo_ribistvo/04_rastlinska_pridelava/01_15024_pridelki_povrsina/01_15024_pridelki_povrsina.asp (Citirano 1. 12. 2013).

Principles of organic agriculture. 2012. International Federation of Organic Agriculture Movements (IFOAM). URL: http:/www.ifoam.org/en/organic-landmarks/principles-organic-agriculture (Citirano 20. 6. 2012).

Sameh, A. M., Abd El-Mageed, A. E., El-Metwally, M. M., Ghanim, N. M., 2010. Efficacy of Spinosad, Lufenuron and Malathion against olive fruit fly, Bactrocera oleae (Gmelin) (Diptera: Tephritidae). Egyptian Academy Journal of biological sciences, A. Entomology, 2, 2, str. 171-178. URL: http:/entomology.eajbs.eg.net/pdf/vol2-num2/17.pdf. (Citirano 10. 6. 2012).

Santucci, F. M., 2007. Organic olive oil and rural development: which services are required and who can supply them? Speech at XVIII European seminar on extension education, Prague, str. 5-8. URL: http://orgprints.org/13532/1/ESEE07-oil-Fulltextrev.pdf (Citirano 15. 6. 2012).

Schwarz, G., Nieberg, H., Sanders, J., 2010. Organic farming support payments in the EU. Johann Heinrich von Thünen-Institut, special issue, 339. URL: http://www.bfafh. de/bibl/lbf-pdf/landbauforschung-sh/lbf_sh339.pdf (Citirano 9. 6. 2012).

Slabe, A., Lampič, B., Juvančič, L., 2011. Potenciali ekološke pridelave za trajnostno lokalno oskrbo s hrano v Sloveniji. Dela, 36, str. 93-109.

Tate, W. B., 1994. The development of the organic industry and market: an international perspective. V: Lampkin, N. H., Padel, S. (ur.). The economics of organic farming: an international perspective, Wallingford, CAB International, str. 11-25.

Terenska raziskava: Značilnosti ekološkega kmetovanja v Slovenski Istri. 2009.

Udovč, A., 2001. Kmetijska okoljska problematika in reforma kmetijske politike v Sloveniji. V: Erjavec, E., Juvančič, L. (ur.). Učinki reforme slovenske kmetijske politike. Ljubljana, Društvo agrarnih ekonomistov Slovenije, str. 101-111.

Vrhovnik, I., 2005. Oljčniki v številkah. Oljka, 1, str. 10-12. 


\section{ORGANIC OLIVE GROWING IN SLOVENIA}

\section{Summary}

The contribution focuses on organic olive production, which has been gaining in importance over the recent years in Slovenia, mainly in Slovenian Istria, where practically all the (organic) olive orchards are located. The contribution is based on a detailed analysis of the data collected by the Ministry of Agriculture and Environment, and on a field survey of olive growers included in organic control. Based on the obtained results, we (critically) present the developmental trends, the spatial characteristics, production, marketing and socio-economic characteristics of organic olive production.

In 2012, a record level of more than a $100 \%$ increase in organic olive production was recorded, as the area of the olive orchards involved in organic control rose to 184.5 ha. On average, organic farms produce olives on an area of 1.34 ha, which is more than on conventional and integrated farms. As many as 29 farms cultivate olive orchards with a total area of more than 2 ha. In total, organic farms have produced around 225 tons of olives in 2012.

The spatial analysis showed that nearly $56 \%$ of all organic olive orchards in Slovenia are located in the Koper municipality, while almost $22 \%$ are in the municipality of Piran, and $20 \%$ in the municipality of Izola. Among the settlements, Krkavče stands out, where there is the largest recorded area of organic olive orchards (around $21 \mathrm{ha}$ ). Most of the organic olive orchards are located on the (slightly) elevated positions of flysch hilly areas, where the conditions for (organic) olive cultivation are most suitable, particularly in terms of the incidence of diseases and pests.

Besides favorable natural conditions and, consequently, the fact that the conversion to organic olive production presents no major risks to farmers, the growth of this practice was, in our opinion, primarily influenced by the following factors:

- the availability of an effective remedy (GF-120) against the olive fruit fly (Bactrocera oleae) and various fertilizers and additives;

- economic motives (financial support, higher selling prices for organic olive oil and comparable yields);

- the announced abolishment of integrated production;

- positive experiences of olive growers who had previously opted for organic production, and

- the popularization of organic farming with a growing demand for organically produced foods.

Due to the growth of olive orchards, the latter is already gaining ground, as olive orchards included in organic farming control encompass more than $10 \%$ of all olive orchards in the country. However, given the natural conditions and trends, organic olive growing still has many opportunities for development. In the future, we can thus expect a further growth of organic olive production, also at the expense of abolishing the financial supports for integrated olive oil production in the Rural development plan 2014-2020. 
With the increasing supply of organic olive oil, it will be necessary to strengthen the promotional and marketing activities directed at enhancing the visibility, consumer awareness and, consequently, stimulating domestic consumption.

We can resume that organic farmers devote too little attention to sustainable agricultural practices, such as green manuring, biotic protection, animal breeding in olive orchards, intermediate crops, etc., which raises critical reflections regarding the fulfillment of the essential standards of organic farming. Thus it would be necessary to pay more attention to suitable expert support, awareness raising and education of (organic) olive growers in the future.

(Translated by Tony Pustovrh) 